\title{
Right-Sized Consumption: Should Doughnut Economics \\ Inform the Textile and Apparel Industry?
}

Jana M. Hawley, PhD

University of North Texas

Depending on your point of view, and perhaps even your political leanings, consumerism can be fundamental and benign or rampant and dangerous. No doubt, it is often a hot debate. A few years ago, the marketplace drove our consumption behavior with monikers such as "retail therapy" or "shop "til you drop". More recently, however, consumers began to replace over-thetop consumption with mindful and intelligent consumption. One of the toughest challenges our industry faces is how to Right-Size Consumption in a way that supports our environment while at the same time sustains business profitability. Companies are scrambling to find the right balance that meets this consumer shift while at the same time endures the demands of shareholders in a capitalist marketplace. Right-sized consumption is embedded in important economic, political, and social issues. Major corporations measure their success by stock market performance and constantly strive to sell more and more so that shareholders are happy. On the other hand, consumers are moving away from excessive consumption to a more mindful approach that honors substance and sense of purpose (Havas, June 15, 2010). As this shift occurs, a new economic model needs to be developed that allows businesses to flourish in an environment where sustainability becomes more important than quantity of sales. The purpose of this concept paper is to inspire a discussion on how ITAA scholars can begin to develop an economic model of sustainability where environment, economics, and humans not only co-exist-- but thrive. I do not claim to have the answers. I only hope that interested scholars can form a collaboration that ultimately forms a new economic model that supports today's concerns on sustaining the economy, the earth, and humans.

The Challenge of Neoclassical Economics

Sustainability discussions have received much attention among ecologists, environmental engineers, textile and apparel scholars, and other members of the scientific community. Even though sustainability is clearly rooted in economic behavior, economists have remained one of the most reluctant disciplines to address sustainability. Conventional economic theory is rooted in the belief that there are no limits to growth. They believe that human ingenuity is infinitely substitutable for limited naturel resources. Traditional economic models are based on using up resources in ways that accurately reflect the tastes and preferences of individual consumers. Society, the environment, and even preferences for no-consumption goods are considered external to the economic decision making process. These theories go back to the days of Rostow

Published under a Creative Commons Attribution License (https://creativecommons.org/licenses/by/4.0/), which permits unrestricted use, distribution, and reproduction in any medium, provided the original work is properly cited.

ITAA Proceedings, \#76 - https://itaaonline.org 
(1959) where economic growth was outlined through 5 easy steps leading, finally, to high-mass consumption. However, the paradigm of the 20th century no longer holds true in today's world.

The Issue of Sustainability

The emergence of sustainability as a major public issue reflects a fundamental challenge to the assumption of unlimited growth. Sustainability is people-centered (Ikerd, 1997). It is about sustaining a desirable quality of life for future generations. A common definition is, "practices that preserve the balance between human needs and the environment, as well as between current and future human requirements" (UN World Commission, 2009). A commentary in The Lancet argues that we must think about 'well-being' rather than sustainability where well-being depends on enabling every person to lead a life of dignity and opportunity, while safeguarding the integrity of Earth's life-supporting systems (Lancet, 2017).

\section{A New Economic Model of Sustainability}

It has become clear that $20^{\text {th }}$ century economic theories of unlimited growth no longer make sense in a world where environmental degradation warnings are commonplace. In an April 2018 TedTalk, Oxford economist, Kate Raworth proposed the Doughnut Economic Model for the $21^{\text {st }}$ century. She argues that growth economics no longer work and proposed a new doughnut-shaped model. The doughnut model proposes that we transform our capitalist worldview obsessed with growth into a more balanced, sustainable perspective that allows both humans and our planet to thrive. While Raworth's work certainly takes a giant step forward in rethinking economics, we must ask whether the doughnut model fits with the sustainability and economic issues of the textile and apparel industry.

It is time for textile and apparel scholars to come together to develop its own model of economic sustainability. Our programs are often deeply connected to industry as we prepare our students for careers. So how do we balance the need for new perspective at the same time we much steward are relationships with industry? How do we nudge industry to make better decisions that support social and planetary needs? How do we muster the ethical courage required to make sure that our industry thrives well into a long-view of the future?

Finally, this concept paper has led to the submission of grant seed funding that would partially fund a scholarly retreat of a team of scholars from various institutions who have similar interests and a passion to make a difference. Each team member will also be expected to contribute financially to the budget (e.g. airfare). The team of scholars would convene in a remote location that provides opportunity for focus, team building, and deep thinking. World Café and QFT techniques will be used to explore a new economic model of sustainability. The team of scholars

Page 2 of 5

Published under a Creative Commons Attribution License (https://creativecommons.org/licenses/by/4.0/), which permits unrestricted use, distribution, and reproduction in any medium, provided the original work is properly cited.

ITAA Proceedings, \#76 - https: / /itaaonline.org 
will be expected to move forward with outcomes that can be disseminated to all members of ITAA.

\section{References}

Havas Global Comms. (June 15, 2010) $72 \%$ are shopping more carefully and mindfully than they used to. Retrieved from https://download.havas.com/prosumer-reports/the-new-consumer-in-theage-of-mindful-consumption/.

Ikerd, J. E. (1997). Toward an economics of sustainability. Retrieved from http://web.missouri.edu/ ikerdj/papers/econ-sus.htm.

Raworth, K. (2018, April). A healthy economy should be designed to thrive, not grow [TedTalk]. Retrieved from https://www.ted.com/talks/kate raworth a healthy economy should be designed to thrive not $\mathrm{gr}$ ow/transcript?language=en.

Rostow, W.W. (1959). The stages of economic growth. The Economic History Review, 12(1), 116.

The Lancet. (2017, May). A doughnut for the Anthropocene: humanity's compass in the $21^{\text {st }}$ century. .Retrieved from https://www.thelancet.com/pdfs/journals/lanplh/PIIS2542-5196(17)300281.pdf.

UN World Commission. (2009). Our Common Future Report. Retrieved from http://www.undocuments.net/wced-ocf.htm. 
Published under a Creative Commons Attribution License (https://creativecommons.org/licenses/by/4.0/), which permits unrestricted use, distribution, and reproduction in any medium, provided the original work is properly cited.

ITAA Proceedings, \#76 - https://itaaonline.org 
